\title{
Encouraging Student with Selective Mutism through ABA Approach
}

\author{
Didin Sahidin $^{1}$, Ari Kartini ${ }^{2}$, Umi Kulsum ${ }^{3}$,Deasy Aditya Damayanti ${ }^{4}$ \\ \{Didinsahidin@institutpendidikan.ac.id ${ }^{1}$, arikartini@institutpendidikan.ac.id², umikulsum@institutpendidikan.ac.id ${ }^{3}$, \\ deasyaditya@institutpendidikan.ac.id $\left.{ }^{4}\right\}$ \\ Institut Pendidikan Indonesia, J1. Terusan Pahlawan No. 32, Garut 44151 1,2,3,4
}

\begin{abstract}
Speech disorders can be affected by multifactorial causes, one of which is mutism. Mutism will interfere with one's communication process and hence will affect their social life. Mutism case does not only occur to children with special needs but also to children without disabilities. Therefore, proper intervention is required for those with mutism. ABA (Applied Behavior Analysis) approach can be an alternative approach to treating students with mutism. This descriptive case study showed that ABA approach could improve the speaking skills of student with mutism. It is therefore suggested that ABA approach be integrated into school curriculum so as to help students with multifactorial disorders.
\end{abstract}

Keywords: Mutism, Applied Behavior Analysis approach.

\section{Introduction}

Speech problems can be affected by multifactorial causes such as lack of vocabulary knowledge, unclear pronunciation, and mutism. Speech disorders can be classified into four: speech disorders in children with intellectual disability, speech disorders in children with hearing impairment, speech disorders in children with autism, speech disorders in children with brain injuries [1]. Speech disorders can also occur to children with selective mutism. Selective mutism is a childhood psychological and behavioral disorders characterized by a child's inability to speak and refusal to communicate in social settings [2]. Children with selective mutism will experience anxiety caused by consistent speaking failures in particular settings such as home, school, or other social environments, resulting in a significant decline in academic or social achievement [3].

Previous research suggest that the anxiety level could be an initial indicator for selective mutism, especially in bilingual children [4]. Selective mutism has once been treated with IBTSM (Integrated Behavior Therapy for Selective Mutism). The results of his research show that IBTSM seems to be a promising new intervention in improving functional speaking behavior [5].

Selective mutism can be caused by different factors. Each one of selective mutism cases requires an in-depth study and different approach from one to the other. Knowing the cause of selective mutism is a must before giving any treatment. This paper discusses an intervention given to a student with selective mutism. The intervention was planned, selected, and conducted after a preliminary study found that in this case the selective mutism was caused by a traumatic 
factor. The intervention used Applied Behavior Analysis (ABA) approach. This approach is an alternative approach to treating students with selective mutism. The principles and procedures of ABA approach has been used to treat a variety of social problems such as low academic achievement and addiction [6]. ABA has been defined as the application of approaches, methods, procedures, and techniques derived from experimental analysis of behavior (EAB) in various clinical and social institutions. The main assumption explains that the consequences of environmental variables can be used to produce behavioral changes [7]. Therefore, ABA approach could to be suitable for treating children with selective mutism.

\section{Methods}

\subsection{Objective of the study}

The present study was conducted as a follow-up to a previous study on a student indicated to have selective mutism. The treatment used ABA approach through table top activities and parenting refreshing.

\subsection{Participants}

The subject of this study was a single student. He was not a student with special needs. He was a fourth grader at a regular school. For the past three years, he had been reluctant to speak at school and at public places new to him.

\subsection{Procedures}

The present study was focused on the conduct of follow-up treatment using ABA approach through table top activities and parenting refreshing. ABA is derived from Ivan Pavlov's operant conditioning theory and Thorndike's classical conditioning. ABA approach is aimed at teaching particular skills and concepts. The goal of the therapy is to slowly train brain nerves so that the subject can think critically and react the same way as other children [8]. ABA is a treatment approach that: (a) is systematically implemented in accordance with the principles of applied behavior analysis, (b) is implemented as earliest as possible in the childhood age, (c) is usually implemented one-to-one before generalization procedures, (d) is individual and comprehensive and targets a large number of skills, (e) combines the target skills according to typical development-based hierarchy, and (f) is used along with parental education services [9].

In the implementation of ABA approach through table top activities, (1) the child is seated face to face with the teacher, (2) the instructional materials are placed on the table, (3) picture cards are used as an instructional media, as a visual support, because children with mutism have difficulties in processing auditory messages, (4) consistent exercises are required because there is no such thing as an instant way as it takes hard works and extra patience in order for the child to exhibit significant progress [10]. While ABA approach through parenting refreshing is all about making the student feel comfortable and happy when he plays. Playing is an important activity for the physical, social, emotional, intellectual and spiritual development of elementary school students. When playing, they get to know the environment, interact with each other, and develop their emotions and imaginations [11]. Figure 1 illustrates the procedures of treatment using ABA approach. 


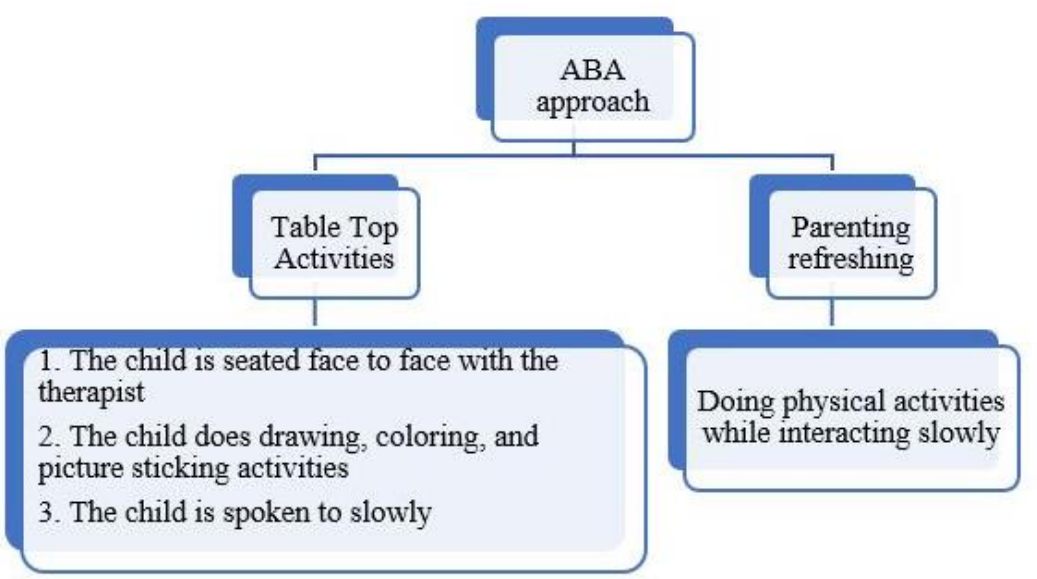

Fig. 1. Treatment procedures using ABA approach

\section{Results and discussion}

\subsection{Applied Behavior Analysis (ABA) approach through table top activities}

Table Top Activities was the first technique of treatment given to the student with selective mutism.

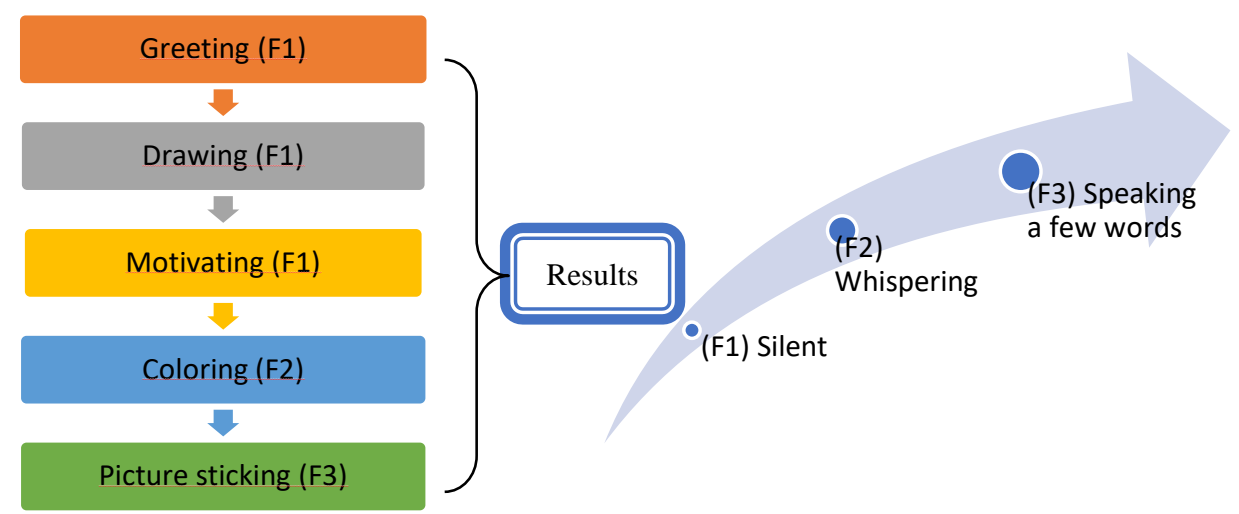

Fig. 2. Results of Treatment Using Table Top Activities

The results of treatment using top table activities were three phases. First, the child was silent while enjoying the drawing activities. Second, the child started whispering one or two words. Third, the child spoke a few words.

\subsection{Applied Behavior Analysis (ABA) through parenting refreshing}

The second technique was parenting refreshing. This treatment was done to help the child with selective mutism establish intimacy and encourage self-confidence in outside environment. The treatment is illustrated in Figure 3. 


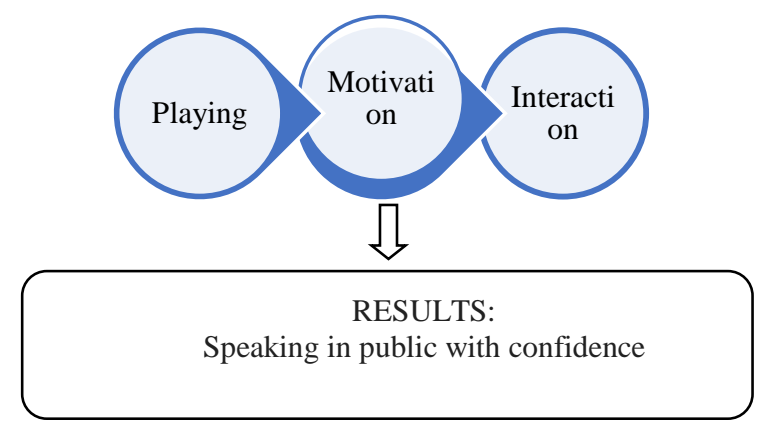

Fig. 3. Results of treatment using parenting refreshing

The treatment using parenting refreshing resulted in changes in speech ability. The subject started to speak in public confidently. Since the major problem was traumatic factor, not linguistic ability, the subject did not have any difficulty of choosing the right words from his vocabulary. He started to look confident when speaking in public.

\section{Conclusion}

ABA approach through table top activities managed to help the student with selective mutism develop trust in people around him, so he is willing to speak up despite three phases: silent, whispering, and speaking and to help him adapt to the environment and build up selfconfidence in social interaction. The student with selective mutism, who was initially reluctant to speak for the past three years, now began to speak confidently. Therefore, it is highly recommended that $\mathrm{ABA}$ approach can be adopted and integrated into school curriculum.

\section{References}

[1] Indah, R.: Proses Pemerolehan Bahasa dari Kemampuan hingga Kekurangmampuan Berbahasa. Jurnal Lingua UIN Malang. Vol.3 No.1. Accessed 05 February 2019. (2008)

[2] Nieves, M.: Selective Mutism. Encyclopedia of Human Behavior (Second Edition).pp. 302306 (2012)

[3] Bunnell, B.: A Two-Session Hierarchy for Shaping Successive Approximations of Speech in Selective Mutism: Pilot Study of Mobile Apps and Mechanisms of Behavior Change. Behavior Therafy. Pp. 1-15 (2018)

[4] Starke, A.: Effects of Anxiety, Language Skills, and Cultural Adaptation on the Development of Selective Mutism. Journal of Communication Disorders. doi.org/10.1016/j.jcomdis.2018.05.001 (2018). Accessed 05 February 2019

[5] Bergman, R.: Integrated Behavior Therapy for Selective Mutism: A randomized controlled pilot study. Behaviour Research and Therapy. Pp. 680-689 (2013)

[6] Roane, H.: Applied Behavior Analysis as Treatment for Autism Spectrum Disorder. The Journal of Pediatrics. Pp. 1-6 (2016) 
[7] Ardila, R.: Behavior Analysis, Applied. International Encyclopedia of the Social \& Behavioral Sciences, 2nd edition, Volume 2. http://dx.doi.org/10.1016/B978-0-08097086-8.22002-3. Pp. 407-411 (2015). Accessed 05 February 2019

[8] Brown, D. 2007. Teaching by Principles: An Interactive Approach to Language Pedagogy. Jakarta: Pearson Education.

[9] Maria, K.: The effectiveness of applied behavior analytic interventions for children with Autism Spectrum Disorder: A meta-analytic study. Research in Autism Spectrum Disorders. https://doi.org/10.1016/j.rasd.2018.03.006. Pp. 18-31 (2018)

[10] Irawan, A.: Manajemen Perilaku Anak Autis. Diklat Layanan Pembelajaran Anak Autis Tk. Dasar (online) http://id.scribd.com/doc/4. Hal.18 (2009). Downloaded 28 October 2012.

[11] Syaikhudin, A.: Analisis Metode Permainan Sosial untuk Pembelajaran IPS di Sekolah Dasar/Madrasah Ibtidaiyah. Jurnal Pendidikan Islam Ta'Allun. Vol. 1 No. 2. Pp. 171-182 (2013) 